DOI: 10.18276/SIP.2017.47/2-15

\title{
Jan Borowiec*
}

Uniwersytet Ekonomiczny we Wrocławiu

\section{EFEKTY STRATEGII ROZWOJU ZRÓWNOWAŻONEGO UNII EUROPEJSKIEJ}

\begin{abstract}
Streszczenie
Przedmiotem badań są efekty realizacji strategii rozwoju zrównoważonego Unii Europejskiej. Na podstawie analizy wskaźników rozwoju zrównoważonego dokonano oceny postępu w osiąganiu celów tej strategii w poszczególnych państwach członkowskich. Z przeprowadzonych badań wynika, że efekty te są bardzo zróżnicowane w zależności od wymiarów rozwoju zrównoważonego i odpowiadającym im obszarom tematycznym, jak i państw członkowskich. Badania wskazują również na istnienie w Unii ścisłej współzależności między poziomem rozwoju gospodarczego a efektami wdrażania założeń koncepcji rozwoju zrównoważonego, zwłaszcza od odniesieniu do rozwoju społecznego.
\end{abstract}

Słowa kluczowe: rozwój zrównoważony, strategia rozwoju zrównoważonego, Unia Europejska

\section{Wstęp}

Początek historii rozwoju zrównoważonego to lata 80. XX wieku. Od lat 90. jest on przedmiotem działań podejmowanych na arenie międzynarodowej, w tym przede wszystkim w ramach Organizacji Narodów Zjednoczonych. Wspieranie rozwoju

\footnotetext{
* Adres e-mail: jan.borowiec@ue.wroc.pl.
} 
zrównoważonego jest także jednym z celów Unii Europejskiej. W 2001 roku Rada Europejska w Göteborgu przyjęła strategię rozwoju zrównoważonego, odnowioną pięć lat później. Określiła ona cele rozwoju zrównoważonego oraz działania niezbędne do ich osiągnięcia.

Celem artykułu jest ocena efektów realizacji tej strategii zarówno w całej Unii, jak i w poszczególnych państwach członkowskich. Zastosowaną metodą badawczą jest analiza wskaźników rozwoju zrównoważonego uzupełniona statystyką opisową i analizą korelacji. Ocena stanu rozwoju zrównoważonego dotyczy 2015 roku. Wskaźniki bazowe dla poszczególnych wskaźników odnoszą się jednak do różnych lat. Źródłem danych jest Eurostat.

\section{Strategia rozwoju zrównoważonego Unii i jej uwarunkowania międzynarodowe}

W raporcie Światowej Komisji ds. Środowiska i Rozwoju Nasza wspólna przyszłość zdefiniowano pojęcie „rozwoju zrównoważonego” jako taki rodzaj rozwoju, który zaspakaja obecne potrzeby, nie ograniczając możliwości zaspokojenia potrzeb przyszłych pokoleń (The World Commission on Environment and Development, 1987). Raport zmienił też podejście do rozwoju zrównoważonego, wskazując na konieczność integracji działań w zakresie wzrostu gospodarczego, rozwoju społecznego i ochrony środowiska naturalnego. W czasie szczytu Ziemi w Rio de Janeiro w 1992 roku przyjęto po raz pierwszy program działań na rzecz rozwoju zrównoważonego - Agendę 21 (United Nations, 1992). Podczas szczytu rozwoju zrównoważonego w Nowym Jorku we wrześniu 2015 roku przyjęto nowy program - Agendę 2030 (United Nations, 2015). Wyznaczono w niej 17 globalnych celów rozwoju zrównoważonego i 169 celów powiązanych, które powinny być osiągnięte do 2030 roku.

Rozwój zrównoważony jest również jednym z celów Unii Europejskiej (art. 3 traktatu o Unii Europejskiej). Mając na uwadze to, a także zobowiązania międzynarodowe Unii związane z rozwojem zrównoważonym, Rada Europejska w Göteborgu przyjęła strategię rozwoju zrównoważonego Unii (Presidency conclusions, 2001). W 2006 roku Rada odnowiła strategię przyjętą w Göteborgu. Za ogólne jej cele uznała:

a) ograniczenie zmian klimatu oraz ich kosztów;

b) wspieranie rozwoju zrównoważonych systemów transportowych;

c) promowanie modeli zrównoważonej konsumpcji i produkcji; 
d) poprawę gospodarowania zasobami naturalnymi oraz unikanie ich nadmiernej eksploatacji;

e) promowanie zdrowia publicznego oraz poprawę ochrony przed zagrożeniami dla zdrowia;

f) stworzenie zintegrowanego społeczeństwa oraz zapewnienie obywatelom stabilnej jakości życia;

g) aktywne propagowanie na całym świecie rozwoju zrównoważonego oraz zapewnienie zgodności polityki Unii z globalnymi celami rozwoju zrównoważonego oraz z międzynarodowymi zobowiązaniami (Rada Unii Europejskiej, 2006).

Dla każdego z tych celów zdefiniowano cele operacyjne oraz działania niezbędne do ich osiągnięcia.

Wprowadzenie w życie strategii rozwoju zrównoważonego wymaga opracowania odpowiednich wskaźników. Służą one monitorowaniu realizacji podjętych działań w jej ramach oraz ocenie postępu w osiąganiu jej celów. Urzeczywistnienie Agendy 2030 implikuje konieczność opracowania ponad 300 wskaźników. Podobna ich liczba została przyjęta do monitorowania realizacji strategii OECD „Green Growth” (OECD, 2011). Aby wprowadzić w życie strategię rozwoju zrównoważonego Unii, Eurostat opracował ponad 130 wskaźników (Eurostat, 2015).

\section{Analiza wskaźników rozwoju zrównoważonego w Unii}

Podstawą analizy są wskaźniki rozwoju zrównoważonego Eurostatu, natomiast jej przedmiotem - efekty realizacji strategii rozwoju zrównoważonego Unii w 2015 roku. Badania obejmują również ocenę postępu w osiąganiu jej ogólnych celów. Cele te nie są opisane wartościami liczbowymi. Natomiast taki charakter mają niektóre cele operacyjne, na przykład dotyczące emisji gazów cieplarnianych i pomocy rozwojowej. W odniesieniu do wskaźników rozwoju społeczno-gospodarczego i dobrego rządzenia nie jest możliwe nadanie im wartości liczbowej odpowiadającej celom strategii rozwoju zrównoważonego. Niektóre wskaźniki mają postać indeksów, co może ułatwić ocenę postępu w osiąganiu celów tej strategii.

W tabeli 1 zawarto 11 wskaźników rozwoju zrównoważonego w odniesieniu do następujących obszarów tematycznych: rozwój społeczno-gospodarczy (wskaźnik 1 i 2); zrównoważona konsumpcja i produkcja (wskaźnik 3); włączenie społeczne (wskaźnik 4); zmiany demograficzne (wskaźnik 5); zdrowie publiczne 
(wskaźniki 6 i 7); zmiany klimatyczne i energia (wskaźniki 8 i 9); zrównoważony transport (wskaźnik 10); globalne partnerstwo (wskaźnik 11).

Tabela 1. Wskaźniki rozwoju zrównoważonego Unii Europejskiej w 2015 roku

\begin{tabular}{|c|l|c|c|c|c|c|c|c|}
\hline \multirow{2}{*}{ Lp. } & \multicolumn{1}{|c|}{ Wskaźnik } & \multicolumn{2}{c|}{$\begin{array}{c}\text { Wartość } \\
\text { wskaźnika }\end{array}$} & \multicolumn{2}{c|}{$\begin{array}{c}\text { Odchylenie } \\
\text { standardowe }\end{array}$} & \multicolumn{2}{c|}{$\begin{array}{c}\text { Współczynnik } \\
\text { zmienności }\end{array}$} \\
\cline { 3 - 9 } & & 2000 & 2015 & 2000 & 2015 & 2000 & 2015 \\
\hline 1. & Realny PKB per capita & 22,9 & 26,5 & 14,7 & 16,2 & 64,2 & 61,1 \\
\hline 2. & Wzrost realnego PKB per capita (2000-2015) & \multicolumn{2}{|c|}{1,10} & \multicolumn{2}{|c|}{1,87} & \multicolumn{2}{|c|}{170,0} \\
\hline 3. & Produktywność zasobów & 1,27 & 2,18 & 0,48 & 0,86 & 37,8 & 39,4 \\
\hline 4. & $\begin{array}{l}\text { Zagrożenie ubóstwem lub wykluczeniem } \\
\text { społecznym }\end{array}$ & 25,8 & 23,7 & 11,6 & 6,82 & 45,0 & 28,8 \\
\hline 5. & Stopa zatrudnienia starszych pracowników & 36,9 & 53,3 & 11,5 & 10,2 & 31,2 & 19,1 \\
\hline 6. & Lata życia w zdrowych warunkach & 61,8 & 61,6 & 5,62 & 4,74 & 9,09 & 7,69 \\
\hline 7. & Przeciętne trwanie życia & 76,6 & 80,4 & 3,09 & 2,06 & 4,03 & 2,56 \\
\hline 8. & Emisja gazów cieplarnianych & 92,1 & 77,1 & 29,0 & 27,0 & 31,5 & 35,0 \\
\hline 9. & Konsumpcja energii pierwotnej & 94,5 & 88,0 & 6,89 & 9,39 & 7,29 & 10,7 \\
\hline 10. & Konsumpcja energii w transporcie & 108,6 & 93,5 & 11,1 & 8,50 & 10,2 & 9,09 \\
\hline 11. & Oficjalna pomoc rozwojowa & 0,42 & 0,46 & 0,29 & 0,35 & 68,5 & 75,9 \\
\hline
\end{tabular}

Dane początkowe odnoszące się do wskaźników 4, 5, 6 i 11 dotyczą 2005 roku.

Źródło: opracowanie własne na podstawie http://ec.europa.eu/eurostat/web/sdi/indicators; Human Development Report, 2015, s. 208-211; http://hdr.undp.org/en/data.

PKB per capita pomimo wielu wad jest powszechnie stosowaną miarą poziomu rozwoju gospodarczego. Unia nie jest zrównoważona wewnętrznie pod tym względem, bowiem znaczne są dysproporcje w poziomach rozwoju państw członkowskich. W latach 2000-2015 zmniejszyły się one w wyniku procesów konwergencji realnej; współczynnik korelacji między wyjściowym poziomem PKB per capita a tempem jego wzrostu w tym okresie wynosił - 0,53. Procesy konwergencji nie wystąpiły jednak w niektórych gospodarkach znajdujących się w przejściowej fazie rozwoju, zwłaszcza w Grecji.

Również produktywność zasobów wykorzystywanych w gospodarce jest bardzo zróżnicowana. Zasoby naturalne są efektywniej wykorzystywane w gospodarkach lepiej rozwiniętych aniżeli w słabiej rozwiniętych. W latach 2000-2015 produktywność zasobów zwiększyła się w Unii o 70\%, ale postęp w tej dziedzinie był bardzo 
nierówny. $\mathrm{W}$ dodatku doprowadził do zwiększenia się dyspersji w jej poziomach między państwami członkowskimi.

Wskaźnik zagrożenia ubóstwem lub wykluczeniem społecznym jest jednocześnie wskaźnikiem strategii „Europa 2020” (Komisja Europejska, 2010). Jej celem jest między innymi promowanie włączenia społecznego, w szczególności przez zmniejszenie do 2020 roku liczby ludności zagrożonej ubóstwem lub wykluczeniem społecznym o co najmniej $20 \mathrm{mln}$. W 2015 roku populacja Unii narażona na te zagrożenia była jednak wyższa niż w roku 2008. Ostatni ogólnoświatowy kryzys gospodarczy i finansowy ogólnie nie sprzyjał ograniczaniu tych zagrożeń. Jedyną korzystną zmianą są mniejsze różnice w stopniu tych zagrożeń wewnątrz UE.

Głównym wyznacznikiem zmian demograficznych są procesy starzenia się ludności. Niosą one ze sobą długookresowe skutki zarówno dla rynków pracy, jak i systemów zabezpieczenia społecznego. Wzrost stopnia aktywności starszych pracowników może ograniczyć skutki tych procesów. W stosunku do okresu bazowego aktywność tej grupy pracowników znacznie zwiększyła się w Unii, wyraźnie zmniejszyły się również różnice w stopniu tej aktywności między państwami członkowskimi.

W odniesieniu do zdrowia publicznego wskaźnikami rozwoju zrównoważonego są lata życia w zdrowych warunkach oraz długość trwania życia. Postęp w poprawie stanu zdrowia w Unii jest nierówny. W latach 2005-2015 wydłużeniu się długości trwania życia towarzyszyło obniżenie się liczby lat życia w zdrowych warunkach. Skutkiem tych dwóch przeciwstawnych tendencji rozwojowych są jednak mniejsze różnice w ochronie zdrowia publicznego w Unii.

Zgodnie z protokołem z Kioto, do 2020 roku Unia Europejska powinna obniżyć emisję gazów cieplarnianych o 20\% w stosunku do roku bazowego. W 2015 roku cel ten został już osiągnięty w Unii i większości państw członkowskich. W stosunku do roku bazowego istotnie obniżyła się także konsumpcja energii pierwotnej w gospodarce oraz w sektorze transportu.

W odniesieniu do globalnego partnerstwa strategia rozwoju zrównoważonego Unii zakłada zwiększenie oficjalnej pomocy rozwojowej Unii do 0,70\% jej DNB w 2015 roku. Państwa członkowskie, które przystąpiły do UE po 2002 roku, powinny dążyć do zwiększenie jej rozmiarów do $0,33 \%$ swojego DNB. Cele te nie zostały jednak osiągnięte. Swoje zobowiązania w tym zakresie wypełniły zaledwie cztery państwa: Szwecja, Luksemburg, Dania i Niderlandy. 


\section{Klasyfikacja państw z punktu widzenia efektów rozwoju zrównoważonego}

W tabeli 2 przedstawiono klasyfikację państw członkowskich z punktu widzenia wskaźników rozwoju zrównoważonego. Ustalając kolejność państw, przyjęto następujące założenia:

a) każde państwo zostało sklasyfikowane na podstawie poziomu wskaźników rozwoju zrównoważonego, od wskaźnika najlepszego (pierwsze miejsce w klasyfikacji) do wskaźnika najgorszego (ostatnie miejsce w klasyfikacji);

b) klasyfikacja odnosi się do obszarów rozwoju zrównoważonego; gdy dany obszar charakteryzują dwa wskaźniki, wskaźnik dla tego obszaru jest średnią arytmetyczną ich miejsc w klasyfikacji;

c) ostatecznie o kolejności państw decyduje suma ich miejsc w klasyfikacji w odniesieniu do wszystkich obszarów rozwoju zrównoważonego.

Tabela 2. Klasyfikacja państw członkowskich z punktu widzenia wskaźników rozwoju zrównoważonego

\begin{tabular}{|c|l|c|c|c|c|c|c|c|c|c|}
\hline \multirow{3}{*}{ Miejsce } & \multirow{3}{*}{ Państwa członkowskie } & \multicolumn{6}{|c|}{ Miejsce w klasyfikacji w odniesieniu do poszczególnych } \\
& & A & B & C & D & E & F & G & H & $\Sigma$ \\
\hline & Szwecja & 3 & 20 & 2 & 1 & 1 & 21 & 11 & 1 & 60 \\
\hline 1. & 6 & 4 & 3 & 6 & 9 & 20 & 10 & 4 & 62 \\
\hline 2. & Niderlandy & 9 & 12 & 5 & 3 & 16 & 8 & 8 & 3 & 64 \\
\hline 3 & Dania & 13 & 1 & 15 & 5 & 12 & 4 & 11 & 5 & 66 \\
\hline 4. & Zjednoczone Królestwo & 2 & 2 & 9 & 26 & 7 & 18 & 3 & 2 & 69 \\
\hline 5. & Luksemburg & 1 & 9 & 17 & 10 & 3 & 22 & 2 & 11 & 75 \\
\hline 6. & Irlandia & 4 & 8 & 11 & 2 & 16 & 14 & 16 & 7 & 78 \\
\hline 7. & Niemcy & 22 & 6 & 5 & 14 & 3 & 18 & 20 & 9 & 97 \\
\hline 8. & Francja & 6 & 5 & 20 & 18 & 2 & 15 & 13 & 19 & 98 \\
\hline 9. & Hiszpania & 13 & 7 & 12 & 22 & 9 & 11 & 17 & 8 & 99 \\
\hline 10. & Belgia & 9 & 16 & 8 & 17 & 26 & 5 & 1 & 22 & 104 \\
\hline 11. & Słowacja & 16 & 18 & 1 & 11 & 14 & 12 & 18 & 19 & 109 \\
\hline 12. & Republika Czeska & 6 & 23 & 16 & 4 & 25 & 15 & 5 & 15 & 109 \\
\hline 12 & Estonia & 26 & 3 & 21 & 16 & 5 & 6 & 23 & 12 & 112 \\
\hline 14. & Włochy & 9 & 11 & 13 & 24 & 7 & 28 & 7 & 14 & 113 \\
\hline 15. & Malta & & & & & & & \\
\hline
\end{tabular}




\begin{tabular}{|c|l|c|c|c|c|c|c|c|c|c|}
\hline \multirow{2}{*}{ Miejsce } & \multirow{8}{*}{ Państwa członkowskie } & \multicolumn{8}{|c|}{ Misce w kasyfikacji w odniesieniu do poszczególnych } \\
\cline { 3 - 12 } & & A & B & C & D & E & F & G & H & $\Sigma$ \\
\hline 16. & Finlandia & 16 & 24 & 4 & 8 & 18 & 26 & 26 & 6 & 118 \\
\hline 17. & Austria & 5 & 15 & 7 & 19 & 14 & 27 & 22 & 10 & 119 \\
\hline 18. & Portugalia & 27 & 21 & 18 & 13 & 15 & 15 & 15 & 14 & 135 \\
\hline 19 & Cypr & 25 & 10 & 22 & 15 & 9 & 22 & 9 & 24 & 136 \\
\hline 20. & Węgry & 22 & 19 & 19 & 21 & 22 & 3 & 14 & 18 & 138 \\
\hline 21 & Litwa & 9 & 22 & 24 & 7 & 28 & 1 & 25 & 24 & 140 \\
\hline 22. & Słowenia & 16 & 13 & 10 & 27 & 21 & 24 & 21 & 15 & 147 \\
\hline 23 & Lotwa & 13 & 25 & 25 & 25 & 27 & 12 & 4 & 24 & 155 \\
\hline 24 & Grecja & 27 & 17 & 26 & 28 & 5 & 10 & 24 & 19 & 156 \\
\hline 25. & Polska & 20 & 23 & 14 & 20 & 18 & 24 & 6 & 22 & 157 \\
\hline 26 & Chorwacja & 24 & 14 & 23 & 23 & 23 & 7 & 27 & 24 & 165 \\
\hline 27. & Rumunia & 19 & 27 & 27 & 27 & 24 & 2 & 19 & 24 & 169 \\
\hline 28. & Bułgaria & 21 & 28 & 28 & 28 & 20 & 8 & 28 & 24 & 185 \\
\hline
\end{tabular}

A - rozwój społeczno-gospodarczy, B - zrównoważona konsumpcja i produkcja, C - włączenie społeczne, D zmiany demograficzne, E - zdrowie publiczne, F - zmiany klimatyczne i energia, G - zrównoważony transport, $\mathrm{H}$ - globalne partnerstwo.

Źródło: opracowanie własne na podstawie http://ec.europa.eu/eurostat/web/sdi/indicators; Human Development Report, 2015, s. 208-211.

Państwem członkowskim najbardziej zaawansowanym w urzeczywistnianiu rozwoju zrównoważonego jest Szwecja. W największej mierze odnosi to się do rozwoju społecznego i globalnego partnerstwa. Jej wskaźniki w tych dwóch obszarach są znacznie wyższe od podobnych wskaźników państw członkowskich zajmujących również czołowe miejsca w tym rankingu. Najgorsze wskaźniki rozwoju zrównoważonego mają kraje o najniższych poziomach realnego PKB per capita w Unii Bułgaria, Rumunia, Chorwacja, Polska i Grecja.

Klasyfikacja ta wskazuje również na relatywnie silne ekonomiczne uwarunkowania rozwoju zrównoważonego. W pierwszej dziesiątce rankingu państw członkowskich jest dziewięć państw, których realny PKB per capita jest wyższy od średniego jego poziomu w UE. Na dużą rolę tych uwarunkowań wskazują również wyniki analizy korelacji. Współczynnik korelacji rankingu państw członkowskich z punktu widzenia realnego $\mathrm{PKB}$ per capita $\mathrm{z}$ ich rankingiem z punktu widzenia efektów roz- 
woju zrównoważonego wynosi 0,84 . Efekty rozwoju zrównoważonego na Słowacji oraz w Republice Czeskiej i Estonii dowodzą jednak, że relatywnie niski poziom rozwoju gospodarczego nie stanowi przeszkody w skutecznym wdrażaniu tej strategii.

Wśród dziesięciu państw członkowskich mających ogólnie najlepsze wskaźniki rozwoju zrównoważonego nie ma ani jednego państwa, którego wskaźniki wskazywałyby na istnienie pewnej równowagi we wdrażaniu rozwoju zrównoważonego, z jednoczesnym uwzględnieniem wszystkich jego wymiarów. Wśród krajów lepiej rozwiniętych ścisły związek między poziomem rozwoju gospodarczego a poziomem rozwoju społecznego istnieje tylko w Szwecji. Najsłabsza jest jednak zależność między poziomem rozwoju gospodarczego a ochroną środowiska. Na przykład najlepsze rezultaty w redukcji rozmiarów emisji gazów cieplarnianych mają wyłącznie kraje słabiej rozwinięte.

\section{Podsumowanie}

Efekty realizacji strategii rozwoju zrównoważonego Unii są zróżnicowane. W odniesieniu do zmian klimatycznych Unia wywiązała się już ze swoich międzynarodowych zobowiązań. Zauważa się także wyraźny postęp w osiąganiu innych celów rozwoju zrównoważonego związanych z ochroną środowiska. Poprawia się także spójność gospodarcza Unii dzięki konwergencji realnej. Procesy wyrównywania się poziomów rozwoju gospodarczego nie wystąpiły jednak w niektórych krajach znajdujących się w przejściowej fazie rozwoju. Najgorsze rezultaty osiągnięto w dziedzinie rozwoju społecznego. Postępowi w osiąganiu celów związanych ze zmianami demograficznymi towarzyszył regres w osiąganiu celów dotyczących włączenia społecznego oraz życia w zdrowych warunkach. Stopień urzeczywistniania tych celów jest bardzo wrażliwy na zmiany koniunkturalne, które ze względu na ostatni ogólnoświatowy kryzys gospodarczy i finansowy nie sprzyjały ich osiąganiu po 2007 roku.

Wprowadzenie w życie strategii rozwoju zrównoważonego jest uwarunkowane czynnikami ekonomicznymi. Kraje lepiej rozwinięte mają na ogół lepsze wskaźniki rozwoju zrównoważonego od krajów słabiej rozwiniętych. Z doświadczeń niektórych państw wynika jednak, że niższy poziom rozwoju gospodarczego nie stanowi przeszkody w skutecznym jej wdrażaniu, a także że wyższemu jego poziomowi niekoniecznie odpowiadają odpowiednie efekty rozwoju zrównoważonego. Na efekty te wywierają wpływ również inne czynniki, w tym środowisko przyrodnicze, cechy 
strukturalne gospodarki, stopień rozwoju systemów społecznych oraz preferencje polityczne związane z rozwojem społeczno-gospodarczym.

\title{
Literatura
}

http://ec.europa.eu/eurostat/web/sdi/indicators (14.02.2017).

http://hdr.undp.org/en/data (14.02.2017).

Human Development Report 2015 (2015). United Nations Development Programme. New York.

Komisja Europejska (2010). Europa 2020. Strategia na rzecz inteligentnego i zrównoważonego rozwoju sprzyjajacego włąceniu społecznemu, KOM(2010) 2020 wersja ostateczna.

OECD (2011). Towards Green Growth: Monitoring Progress: OECD Indicators. Paris. Pobrane z: http://dx.org/10.1787/9789264111356-en (14.02.2017).

Presidency conclusions (2001). Göteborg European Council, 15-16 June.

Rada Unii Europejskiej (2006). Przeglad strategii UE dotyczacej trwatego rozwoju (EU $S D S)$ - Odnowiona strategia. Bruksela, 9 czerwca.

The World Commission on Environment and Development (1987). Our Common Future. Oxford University Press.

Traktat o Unii Europejskiej (2016), Dz.U. C 202, 7.06.2016.

United Nations (1992). Agenda 21. Rio de Janeiro: United Nations Conference on Environment and Development, 3-14 June.

United Nations (2015). Transforming our world: The 2030 Agenda for Sustainable Development. Sustainable Development Summit 2015, New York, 25-27 September.

\section{THE EUROPEAN UNION SUSTAINABLE DEVELOPMENT STRATEGY}

\begin{abstract}
The subject of the research are the effects of the EU's sustainable development strategy. Based on the analysis of indicators of sustainable development an assessment of the progress in achieving the objectives of this strategy in the Union and the Member States has been made. The studies show that the effects vary depending on the dimensions of sustainable development and the corresponding thematic areas and on the Member States. There is
\end{abstract}


a close correlation between the level of economic development and the effects of implementing the concept of sustainable development, especially with regard to social development.

Translated by Jan Borowiec

Keywords: European Union, sustainable development, sustainable development strategy

JEL Codes: F15, F63, Q01 